\title{
Research of the incentive problems of the New Generation of Migrant Workers
}

\author{
Peng Qingxiu \\ Zhengzhou University of light Industry \\ Zhengzhou, China \\ e-mail:473884715@qq.com
}

\author{
Zhao Chaojie \\ Zhengzhou University of light Industry \\ Zhengzhou, China \\ e-mail:363671360@qq.com
}

\begin{abstract}
To speed up the new generation migrant workers' incentive security measures to meet their interest appeal is China's current economic and social development problems to be solved. This article analyzed the Demand situation and the interests of the new generation of migrant workers, paid much attention to their new characteristics, new demands and new problems, then explored a new mechanism for the new generation of migrant workers' incentive problems.
\end{abstract}

Keywords- incentives; generation of migrant workers; aspirations

\section{INTRODUCTION}

The new generation of migrant workers is the famers who were born after 1980, mostly under the age of 30 now. There are about 150 million migrant farmer workers in China, the new generation of migrant worker have reached about 100 million people, and have become an important part of the migrant workers groups. Generation of migrant workers created huge economic benefits for the country, but the problems are not optimistic and become increasingly prominent contradiction, so the incentive problems are now attracting the society's close attention.

\section{THE CHARACTERISTICS OF THE NEW GENERATION OF MIGRANT WORKERS}

\section{A. Level of education improved}

The education level of the new generation of migrant workers have improved significantly compared to the old generations, $67.2 \%$ of them have high school or higher education experience. But judge from the contents of education, there are only less than forty percent received professional technical education, $60 \%$ of the new generation of migrant workers still stay in the primary education stage, far behind the urban works' level.

B. The new generation of migrant workers' growing experiences convergence in urban peers

Most of the new generation of migrant workers follow his parents moved to the city from an early age, there are familiar with the living environment of the city; even those who were born and grew up in rural, are not familiar with agricultural production and also do not want to do farm work on the farmland in rural areas, they do not miss the land and rural just as the city peers.

\section{Have strong self-awareness}

The new generation of migrant workers like the city of young people, love to dress up, surf Internet, go shopping, have poor tolerance. They are more favored to go to the manufacturing sector, the service sector, and the proportion of the dirty and tired construction employment decreased year by year.

\section{Most of the workers are not married}

The new generation peasant workers have been married for only about $20 \%$, because they expect to live in the city, go down from love, marriage, birth to children, all the problems need to be resolved during work outside.

\section{THE DIFFERENCE BETWEEN THE NEW AND THE OLD GENERATION OF MIGRANT WORKERS}

New generation peasant workers and the traditional concept of peasant workers in there are some obvious differences, in summary, concentrated embodied in "four changes".

A. Employment motivation changes from "improve life" to "experience life and pursuit dreams"

The main purpose of the traditional migrant workers traveling to work is to earn tickets, build a house, marry a wife and have babies, in short, in order to improve the living conditions of the comparison famine. But the new generation of migrant workers is young and their career path has just begin, the working motivation with age stage characteristics. Use the words of a 26-year-old new generation of migrant workers in field research is that they want to experience life, to realize their dream.

B. Demands for labor rights shift from simple basic labor rights and interests to decent work and overall develop opportunities

In the $1980 \mathrm{~s}$, migrant workers just in a large scale in China, they are out in the employment of relatively simple purpose - to make money, so the demands of the labor rights is also relatively low, even thought that social security and occupational health and other labor rights and interests are non-essential as long as received payment for labor in time and in full. For the new generation of migrant workers, employment background, family environment and the different level of personal and cultural skills create a relatively relaxed environment for them to work outside. The demands of their labor rights and interests have reached a higher level. In their words, only a fool will go to the kind of work which providing low wages, room and board not 
included, do not sign the contract, the insurance not included and have small develop opportunities.

C. The mentality of working in city has changed from passing traveler psychology to looking forward to the long-term stability life

The way of working of the traditional migrant workers is similar to the migratory birds and the experience as both workers and peasants made their city passing psychology. According to a survey of the families of migrant workers in Tsinghua University, 89.7 percent of the migrant workers will definitely return to their native homes, only $10.3 \%$ of people said they did not return home to settle. However, according to the China Youth Research Center's research report about the new generation of migrant workers, 55.9\% of the people who are prepared to the future "in the city to buy a house and settle", far higher than the $17.6 \%$ of the overall agricultural floating population level.

D. The pursuit of outgoing life turned from want nothing to look forward to getting better mental and emotional life needs

The different ages of the population have different lives and spiritual needs. Most of the traditional migrant workers had married before they went to city for work. In order to achieve the goal of making money, they mostly ignored emotional spiritual life. And the new generation peasant workers have an average age of 23 years old or so, first working age less than eighteen, they are in love and marriage period, ideological hesitate period and emotional high dependence period, they eager to harvest their love, exchange minds and pour out troubles during out. According to a research report of the National Bureau of Statistics, in 2006 , only $20.1 \%$ of the migrant workers live in rental housing and own room; and now the proportion has risen to $37.7 \%$ in current generation of migrant workers, this from the other side showed the strong demand of mental, emotional and family destination.

\section{NEW GENERATION PEASANT WORKERS' INTERESTS APPEAL}

A. New generation of migrant workers have higher expectation for working conditions and environment.

The first three important conditions for the new generation of migrant workers to choose a job are income, play to their expertise and work environment. They no longer bear the pressure of the support the family, and the asymmetry of the intensity of work and wages, they may prefer no employment.

B. Consumer attitudes and values of the new generation of migrant workers have occurred in huge.

Their revenue expenditure is more diversified, more wage income being used for the consumption of urban life to enjoy the city life or have a colorful life. Their work, social security, entertainment and leisure, and the development of space requirements are much higher than their parents.
C. Children's education and social security and other basic public needs are not fully implemented.

The current generation of migrant workers, is still in low proportion of the pension, health care, unemployment insurance, in addition, there are individual schools reject children of migrant workers on the ground of household registration, etc.

$D$. The gap between the ideal and the reality is too large, the demand is difficult to achieve.

Most of the new generation of migrant workers is full of confidence and dreams, but in the face of complex social and living environment, they have no time, no ability to accept the study and training and the channels to improve skills is severe shortage.

\section{E. Lack emotional and spiritual pursues.}

The new generation of migrant workers is in the golden age of dating, love and marriage, but because of the low-wage income, narrow social contact gender imbalance and other factors, they fall into dilemma that there is no time to make friends, no love candidate and no object to talk.

\section{F. Labor rights damage phenomenon outstanding.}

At present, the new generation peasant workers' labor contract rate is low. The issues of the arrears of wages and occupational health security must be resolved. In addition, according to the survey, when the new generation of migrant workers has injury, only $60 \%$ of the employer will pay for medical costs. That is to say, the high medical bills of work-related injuries and occupational diseases are a serious problem for these who's already exist difficulties of medical treatment.

\section{RECOMMENDATIONS FOR THE NEW GENERATION OF MIGRANT WORKERS INCENTIVES}

\section{A. Recommendations for Government}

1) Focus on the new generation of migrant workers put how to solve the problem of migrant workers into the national and local economic and social development planning, and into the resident public budgets. This need take the chance to implement the central "about increasing the coordination of urban and rural development efforts to tamp agriculture rural development foundation certain opinions", take citizens of the new generation of migrant workers as the strategic goals of the coordinated development of urban and rural, put how to solve the problem of migrant workers into the national and local economic and social development planning. Government at all levels should be based on the resident population, put migrant workers' work into the medium-to long-term economic and social development plans and annual plans, clear development goal, refining stage task, ensure resources and measures, divide the work between the leadership and institutions and improve staffing at last. 
2) Improve the peasant workers' social political status. Strengthen the new generation peasant workers' humanistic care. Strengthen media publicity of migrant workers, promote the principles and policies of the party and the country and advertise the significant contribution made by migrant workers, guide labor units to fulfill their social responsibilities seriously and create a good social atmosphere in where everyone would give concern, respect and love to migrant workers. Actively organize a variety of cultural and sports activities suitable for the characteristics of the new generation of migrant workers to enrich their leisure life. Pay attention to strengthen the young worker especially new generation peasant workers' psychological counseling and behavior modification services, increase attention and investment to their mental health and carry out social care activities to help them to improve self-management, self-adjustment to ease the psychological pressure, enhance the anti-pressure ability and establish a healthy and positive life goals. Consider the new generation of migrant workers' love and marriage problems and create the conditions to resolve the problems by organization various activities.

3) Explore further new mechanisms and new methods to protect migrant workers and form a social work pattern. According to the requirements of promoting scientific development, establish the migrant workers' working target responsibility assessment and incentive mechanisms, put the migrant workers' training, income growth, housing, medical treatment, children education, social security and other basic living conditions into the performance evaluation indicator system of the local government. And encourage all localities explore and try new mechanisms and new methods of the new generation of migrant workers' career training, housing improvement, reform of household registration system and high school education of their children based on the facts.

\section{B. Recommendations for enterprise}

1) Establish a reasonable salary system. Enterprises must establish a reasonable salary, improve the treatment of migrant workers appropriately, ensure their basic life and do not default salary or reduce wages to play the health care function of salary. Treatment improved to a certain extent also can be used as "incentive" factors, and this also achieve the purpose of reducing turnover while improving work efficiency. Enterprises can establish a fair, just and reasonable payment mechanism and a performance appraisal system. Remuneration should include not only real wages, but also should include welfare, security factors, working conditions and development opportunities. Within the enterprise should form a harmonious labor relations, build a good partnership between employers and employees, this can enhance organizational commitment of migrant workers, win the driving force for enterprises, obtain enterprise and get a win-win situation for both side.

2) Take effective incentive measures. At present, the enterprise of new generation peasant workers' incentive mode is mainly material incentive. New generation peasant workers are not pure "economic man", they are "social man" and they not only need material incentives also need mental stimulation. Enterprises should take appropriate incentives based on the needs of the new generation of migrant workers. Such incentives can play a role.

3) Focus on employees' development, provide personalized training. Combine the jobs of the employees with their career planning. In fact new generation peasant workers' progress consciousness is very strong. They are more pragmatic, more aware of their own inadequacies than college students. Companies should hire experts to provide them with the correct concept of career planning and professional skills so that they can release the potential ability.

\section{REFERENCES}

[1]Zhang yanling, Li peng. Unemployment Survey of migrant workers [J]. Finance, October 2009

[2]Liu huaiqian. The problems of Chinese migrant workers[M]. Beijing: People's Press, 2005.

[3]Wuyang. The characteristics of the new generation of migrant workers, 《Dong yue lun cong》, August 2009.

[4]Hanchangfu. Migrant workers born after 1990.

www.people.com.cn, February 1st 2010.

[5]"80's, 90's" [D].Southwest University for Nationalities,

November 2010 . 